\title{
A románok nevei Anonymus gesztájában és ami körülöttük van
}

\section{2. rész}

4. Sclaui Bulgarii et Blachii ac pastores Romanorum. Talán célszerü lesz, ha itt az alábbiakban többször tárgyalandó egy-egy szövegrész egészét idézem a Geszta 9. fejezetéből: „Dicebant enim, quod ibi confluerent nobilissimi fontes aquarum Danubius et Tyscia et alii nobilissimi fontes bonis piscibus habundantes, quam terram habitarent Sclaui Bulgarii et Blachii ac p a s to res R o m a n o r u m. Quia post mortem Athile regis terram Pannonie Romani dicebant pas c u a esse eo, quod greges eorum in terra Pannonie pas c e b a ntur, et iure terra Pannonie pascua Rom an orum esse dicebatur, nam et modo Romani pascuntur de bonis Hungarie" (Anon. 1932: 8; vö. Anon. 1937/1999: 45-46; a ritkítás tölem: S. T.). „Elmondták ugyanis, hogy itt a Duna, a Tisza és más jóféle halakban bővelkedő nevezetes folyók vizei folynak össze. A földet szlávok, bolgárok és vlachok, valamint a rómaiak pásztorai lakják, mert Pannónia földjét Attila király halála után a rómaiak legelőnek nevezték, mivel nyájaik ott legelésztek. És joggal nevezték Pannónia földjét a rómaiak legelőjének, mivel most is a rómaiak legelik le Magyarország javait" (Anon. 1999: 16; 1. még Anon. 1988: 196; Anon. 1991: 49; Anon. 2000: 49; Anon. 2006: 57-59; Anon. 2010b: 27; vö. Anon. 2001: 23). A kérdéses passzussal (terram [Pannonie] habitarent Sclaui Bulgarii et Blachii ac pastores Romanorum) kapcsolatban a kutatás nagyobb figyelmet szentelt az ac pastores Romanorum kérdésének, amelyre nekünk is röviden majd ki kell térnünk az alábbiakban. Mindenekelött szemet szúr, hogy az említett latin passzusban a Bulgari $i$ et Blachi $i$ (a ritkítás tőlem: S. T.), és nem a *Bulgari et Blachi szóalakok szerepelnek, ami stilisztikailag nincs összehangolva az előttük levő Sclaui névalakkal (ami persze fordítva is igaz). Tehát a Bulgarii et Blachii - úgy tünik mintha külön csoportot alkotna, hiszen a gesztaszerző a következőképpen is írhatta volna: *Sclaui Bulgari et Blachi ac pastores Romanorum (vagy esetleg *Sclauii Bulgarii et Blachii ac pastores Romaniorum). Anonymus vajon miért nem írta ekképpen, ha a zavar nem a másoló számlájára írandó?

Fontos előre jelezni azt, hogy Anonymusnál a szlávokon (Sclaui) azok a szlávul beszélők értendők, akik a Kárpátokon belül éltek, és nem oroszok, nem lengyelek, nem bolgárok, nem csehek stb. (BENKÖ 1998: 67); valószínü továbbá, hogy a Névtelen elképzelése és meggyőződése szerint ezek a szlávok évszázadokkal korábban is itt éltek a Kárpát-medencében.

A Blachii névformával kapcsolatban fentebb futólagosan néhány kutató véleményére hivatkoztam. Ezenkívül még KRISTÓ GYULA (1978: 656; 1. még DeÉR 1943: 97-98; VÁCZY 1974: 34, 96. jegyz.) nézetéről is szólnék, aki szerint a vlachok

${ }^{*}$ Az 1. részt 1. MNy. 2021: 10-22. DOI: https://doi.org/10.18349/MagyarNyelv.2021.1.10. 
kizárólag a Tiszától keletre szerepelnek Anonymusnál, és a Blachii a kelet-magyarországi (erdélyi és al-dunai) románokat, a pastores Romanorum pedig a nyugat-magyarországi (dunántúli) lakosokat jelöli. Ezzel a véleménnyel csak akkor lehet egyetérteni, ha az anonymusi Pannónia alatt nem a Dunántúl, hanem az egész Magyar Királyság területét értjük. Azonban Anonymus egyértelmüen írja, hogy a Blachii is Pannónia földjét lakják (c. 11; vö. ugyanitt: terram Pannonie usque ad Danubium). Vajon mi késztette a gesztaírót arra, hogy a Blachii-t szerepeltesse Pannóniában? GRZESIK RYSZARD (2016: 31-32) - aki a Blachi névalakot alkalmazza mint többes számú nominativusi formát - e név mögött a frankokat véli látni (hasonlóképpen HÓMAN 1925: 60; TAMÁS 1933: 213; GYÖRFFY 1965: 417-418), akik a 9. században uralkodtak Pannóniában a magyarok bejövetele előtt, a pastores Romanorum-ot pedig a frank papokra vonatkoztatja; feltételezi továbbá, hogy Anonymus forrásául a pannóniai szlávok szájhagyományát használta. Nem könnyü elhinni azonban, hogy a szájhagyomány három évszázad után is fennmaradt volna torzítatlanul.

4.1. Anonymus írásmủvét a korabeli információk is nagyban befolyásolhatták. Ismeretes, hogy a pápa és a bolgár uralkodó között a 13. század elején levélváltások folytak többek között az egyházi unió ügyeivel és a koronaküldéssel kapcsolatban, amelyekben a magyar királyoknak, kivált Imre királynak néha közvetítő, néha ellenző szerep jutott (a pápai diplomácia szempontjából vizsgálja a térség eseményeit SWEENEY 1973b; a témánkba vágó időszak bolgár-magyar kapcsolatairól 1. DMITROV 1998: 117-126). János pápai legátus (Iohannes de Casamaris) 1203 körül III. Ince pápához írt levelében szó esik arról, hogy Kalojan küldöttsége a magyar király udvarát felkereste, amikor a legátus Magyarországon tartózkodott (RI. 6: 230, 140. sz.; LIBI. 3: 318, 8. sz.; HINTNER 1976: 65). A pápának a magyar királyhoz 1204 szeptembere táján intézett leveléből arról értesülünk, hogy a király a legátusnak megígérte, hogy királyságán keresztül ő és a Szentszék más küldöttségei szabadon utazhassanak Bulgariába és Blachiába, valamint vissza (RI. 7: 200, 126. sz.; LIBI. 3: 348, 28. sz.; GI. 119, c. 78; HINTNER 1976: 125). III. Ince Kalojan bolgár uralkodóhoz (regi Bulgarorum) 1207. május 25-én intézett leveléből pedig arról értesülünk, hogy a pápa megkérte a magyar királyt, II. Andrást arra, hogy a bolgár küldöttség szabadon és biztonságban áthaladhasson országán az apostoli székhez (RI. 10: 112, 65. sz.; LIBI. 3: 371, 39. sz.; HINTNER 1976: 218-219; 1. alább a 6.4. szakaszt is). Nem vitás, hogy Imre király, majd II. András udvarában kumulálódtak az információk a Második Bolgár Cárságról.

Anonymus kortársa, III. Ince pápa (1198-1216) leveleiben többször megtalálhatók a Bulgaria et Blachia és a Bulgari et Blachi frázisok (többnyire ragozott alakokban). Például az 1202. november 27-i levelében Nobili viro Caloiohanni domino Bulgarorum et Blachorum uralkodói címzéssel találkozunk. Figyelmet érdemel, hogy a bolgár és vlach uralkodó címzésekor a bolgárok említése majdnem mindig megelőzi a vlachokét. ${ }^{16}$ A szóban forgó két nép- és országnév más

${ }^{16}$ Ritkán fordul elő, hogy a vlachok említése megelőzi a bolgárokét: Rex quoque Blachorum et Bulgarorum (RI. 8: 228-229, 126. sz.), vagy az uralkodói címben a Blachorum hiányzik: domino Bulgarorum (RI. 6: 236-238, 143. sz. LIBI. 3: 320-321, 10. sz.), regi Bulgarorum illustri (RI. 10: 112, 65. sz.), imperator Bulgarorum (RI. 6: 234, 142. sz.; LIBI. 3: 319, 9. sz.). 
pápai levélváltásokban is változatlan sorrendiségben jelenik meg. Kalojan levelében pedig magát imperator Bulgarorum et Blachorum-nak nevezi (RI. 5: 225, 114. sz.; LIBI. 3: 309, 2. sz.; GI. 96, c. 66; 1. még DALL'AGLIO 2019: 172-174). Ízelítöül Ince pápa leveleiből felsorolok néhány idevágó frázist: circa Bulgarorum et Blachorum ecclesiam, domini Bulgarorum et Blachorum (RI. 5: 232, 118. sz.), illustri Bulgarorum et Blachorum regi, populis Bulgarorum et Blachorum, tam in Bulgarie quam Blachie (RI. 7: 3-5, 1. sz.), Archiepiscopo Trinouitano, Bulgarorum et Blachorum primati, in regno Bulgarorum et Blachorum, ecclesia Bulgarie et Blachie, per totam Bulgariam et Blachiam (RI. 7: 6-8, 2. sz.), rex Bulgarorum et Blachorum (RI. 7: 21, 7. sz.), regi Bulgarorum et Blachorum, in Bulgariam et Blachiam, totius Bulgarie ac Blachie primatem (RI. 7: 22-23, 8. sz.), Archiepiscopo Trinouitano, totius Bulgarie et Blachie primati, in Bulgaria et Blachia (RI. 7: 24, 9. sz.); Bulgarorum et Blachorum populos (RI. 7: 28, 13. sz.), in Bulgariam et Blachiam (RI. 7: 199, 126. sz.), in Bulgaria et Blachia (RI. 7: 355, 203. sz.), regi Bulgarorum et Blachorum illustri (RI. 8: 237, 130. sz.), rege Bulgarorum et Blachorum (RI. 8: 244, 133. sz.) stb. A 13. század első évtizedeire nézve így a Második Bolgár Cárság név helyett inkább a Bolgár-Vlach Cárságot illene használni, ha csak a pápai levelekre szorítkozunk. ${ }^{17}$ II. András idejében is ehhez hasonló címzéssel és frázissal találkozunk, mégpedig IX. Gergely pápa 1237es két levelében: Assano domino Blachorum et Bulgarorum (LIBI. 4: 55, 10. sz.); in Bulgaria et Blachia; Assanus dominus Bulgarorum et Blachorum (LIBI. 4: 60-61, 14. sz.); Assano domino Bulgarorum et Blachorum (LIBI. 4: 61, 15. sz.).

Ezek a körülmények nem elegendők ahhoz a feltételezéshez, hogy a Névtelen a Sclaui Bulgarii et Blachii ac pastores Romanorum kifejezéssel rejtett formában utalt volna a Magyar Királyságtól délre kialakult politikai képződményre, a Bolgár-Vlach Cárságra. Ami a Sclaui Bulgarii et Blachii frázist illeti, vajon a szóvégi alakbeli egyenetlenségnek van-e valami üzennivalója, vagy Anonymusnak csupán a sajátos és szeszélyes nyelvezetével s a népnevek egyszerü felsorolásával van dolgunk? Ha ezek a különleges szóvégződések inkább annak nyomaként foghatók fel, hogy Anonymus a szóalakokat saját kezüleg alkotta, akkor ismét ugyanoda lyukadunk ki, hogy a Bulgarii et Blachii frázisnak mégis van valami üzenete. ${ }^{18}$

4.2. További problémák tornyosulnak elénk a pastores Romanorum kifejezés értelmezésében. Vajon volt-e valami, ami arra késztette Anonymust, hogy életre hívja a pastores Romanorum szókapcsolatot, és ehhez van-e köze a Bulgarii et Blachii kifejezésnek? Csak találgatásként említeném meg, hogy az Anonymus korabeli kútfőkben olyan szálak figyelhetők meg, amelyek a Bulgari et Blachi-t (Anonymusnál Bulgarii et Blachii) a rómaiakkal és azok pásztoraival kötik össze.

${ }^{17}$ A Második Bolgár Cárság kialakulásának etnikai és politikai vonatkozású vitatott kérdéséről histográfiai áttekintést nyújt DASKALOV (2015), bár az utóbbi néhány évtized kutatásaira kevésbé tér ki (az utóbbiakról 1. MADGEARU 2017: 10-28; MARKOV 2016).

${ }^{18} \mathrm{Az}$ is elképzelhető, hogy Anonymus valamit kifejezésre akart juttatni azzal, hogy egy népről egy másikkal társítva tesz említést, ami müvében igen gyakran megfigyelhető: Ruthenorum et Cumanorum (c. 8, c. 9), Grecorum et Bulgarorum (c. 14, c. 38, c. 39, c. 41, c. 44), Blasii et Sclavi, Cumanis et Picenatis (c. 25), Sclavos et Boemos (c. 35, c. 36), Sclavos et Bulgaros (c. 11), Sclavorum et Pannoniorum (c. 50) stb. 
III. Ince pápa Kalojannak, a bolgárok és vlachok uralkodójának írt leveleiben - bizonyára azzal a célzattal, hogy az ortodox hitü bolgár $\mathrm{s}$ vlach uralkodót a római egyház kötelékébe irányítsa - olyan kifejezést alkalmaz, mint hogy ősei „Róma városának nemes nemzetségétöl" (de nobili urbis Rome prosapia) veszik eredetüket (RI. 2: 486, 255. sz., LIBI. 3: 308, 1. sz.; 1. még HINTNER 1976: 23-24; SZABADOS 2003: 148-149), valamint a ,rómaiak nemes nemzetségétöl” (ex nobili Romanorum prosapia) származik (RI. 5: 227, 115. sz., LIBI. 3: 311-312, 3. sz.; GI. 98-99, c. 68; 1. még HINTNER 1976: 44-46). Arról is szól, hogy a bolgárok és vlachok egyházáról azt mondják, hogy a rómaiaktól származik hús és vér szerint (circa Bulgarorum et Blachorum ecclesiam, que a Romanis etiam secundum carnem et sanguinem descendisse dicitur; RI 5: 232, 118. sz.; LIBI. 3: 316, 6. sz.; GI. 101, c. 69). Kalojan írja a pápának, hogy Isten emlékeztette őt nemzetségére és hazájára, ahonnan származik, és a Szent Atyát jó pásztornak és minden becsületes keresztény fejének nevezi (sancte pater, tamquam bonus pastor et caput omnium fidelium christianorum; RI. 5: 225, 114. sz.; LIBI. 3: 309-310, 2. sz.; GI. 96, c. 66). Továbbá a bolgárok és vlachok cárjainak nevezi - anakronikusan - Simeont, Pétert és Sámuelt (beate memorie illi imperatores Uulgarorum et Blachorum Symeon, Petrus et Samuel; RI. 7: 14, 4. sz.; LIBI. 3: 334, 16. sz.; GI. 102, c. 70; 1. még BožILOV 2017: 309.), ${ }^{19}$ akik az 1018-ban megdöntött Első Bolgár Birodalom uralkodói voltak, tehát nem voltak vlachok.

Kalojan (imperator omnium Bulgarorum et Blachorum) szintén 1203-ban, valamikor szeptember 8 . után kelt levelében - amelyben ugyanezt ismételte (imperatorum Bulgarorum et Blachorum Symeonis, Petri et Samuelis) - a Magyarország, Bulgaria és Blachia közötti határvonallal kapcsolatos kérdésről (de confinio Hungarie, Bulgarie et Blachie) is említést tesz a pápának, és közli, hogy a magyar király megtámadta és elfoglalta Bulgária öt püspökségét, amelyek az ő cárságához tartoznak (RI. 7: 19-20, 6. sz.; LIBI. 3: 338-339, 19. sz.; GI. 104105 , c. 71 ) ${ }^{20}$ A pápa a bolgárok és vlachok királyának (Bulgarorum et Blachorum regi) 1204. február 25-én írt levelében, utalva a felkenésre és koronázásra arról szól, hogy minthogy a Szentszék az Úr parancsára legelteti az ő juhait, a bolgárok s vlachok népeit (cum ex precepto Domini oves eius pascere teneamur, populis Bulgarorum et Blachorum...), akiket olyan hosszú ideje elválasztottak az anyai keblektől, atyai gondoskodással kívánja ellátni (RI. 7: 5, 1. sz.; LIBI. 3: 325-326, 13. sz.; GI. 109, c. 73; HINTNER 1976: 115-117). Ugyanakkortájt a pápa a magyarországi egyháziakat arra kérte, hogy Leo pápai legátusnak a bolgárok s vlachok népéhez való oda- és visszautazását tiszteletteljesen kezeljék s biztonságát

${ }^{19}$ Hasonló anakronizmus TĂUTU írásában (1964: 382) is megfigyelhető: „duc bulgaro-valaque Ohtum en 1003". FLORIN CURTA (2016: 435-438, 457-458) jól dokumentált írásában úgy véli, hogy a pápa információja, miszerint a vlachok római eredetűek, Konstantinápolyból, az ottani latinoktól származik. (Másképpen MADGEARU 2017: 126-167.)

${ }^{20}$ Az elfoglalás nem lehetett tartós, hiszen 1204-ben a Duna Keve (szerbül Kovin) közelében levő szakasza volt a két ország határa. A magyarok támadása Bulgária ellen a Morava folyó mentén (contra Bulgaros super fluvium Morawa) történhetett 1202 körül (CDES. 265, 373. sz.; RA. 1: 152, 471. sz.; vö. PAULER 1899. 2: 25, 488, 22. jegyz.; TĂUTU 1964: 390-391; SWEENEY 1973: 323; HINTNER 1976: 90-91; DIMITROV 1998: 117-119; MADGEARU 2017: 124, 133-134). 
biztosítsák, továbbá azt írja a bolgárok és vlachok egyházáról, hogy ez mintha nem ismerné meg önmagát, miután elhagyta amaz igazi pásztort, akire Krisztus rábízta juhait, hogy legeltesse őket (...Bulgarorum et Blachorum ecclesiam, [que] tamquam non cognosceret semetipsam illo pastore relicto, cui Christus pascendas commiserat oves suas...; magyar fordítás: ÍF. 415; RI. 7: 28, 13. sz.; LIBI 3: 346, 26. sz.; HINTNER 1976: 116). A pápa 1204. szeptember 15-én kelt leveléből pedig arról értesülünk, hogy amikor Imre király azzal a panasszal fordult hozzá, hogy Iannitius (Kalojan) elfoglalta a Magyar Királyság egy részét, a pápa megjegyzi, hogy Péter és Iannitius két testvér, aki az előző királyok (Péter, Sámuel és a többiek) nemzetségéből származik, elkezdte atyáik földjét nem annyira elfoglalni, mint inkább visszafoglalni (magyar fordítás: ÍF. 422-423; RI. 7: 203-205, 127. sz.; LIBI. 3: 353, 29. sz.; GI. 123-124, c. 79.; RA. 68, 212. sz.; 1. HINTNER 1976: 156-157). Ezek az információk a bolgárokról és a vlachokról nagy vonalakban ismertek lehettek a magyar királyi udvarban, és feltehetőleg befolyással voltak Anonymusra is, amennyiben valamilyen módon hozzájuk jutott. Erre nézve érdemes BENKÖ (2003: 166) szavaira hivatkozni, aki szerint a Geszta nem készülhetett korábban, mint a 13. század tízes évei. A tudós ugyanis azt feltételezi, hogy ,a Magiszter talán még a huszas években is élt, és III. Béla alatti kancelláriai szolgálatának idejét jóval túlhaladva ténykedett hivatalos ügyekben is".

GYŐRY JÁNOS (1948: 64-65) szerint Anonymus kedveli az annominatio-t, amelynek legegyszerübb változata ugyanannak a szónak vagy származékának ismétlése avégett, hogy szójátékot eredményezzenek. A kutató felsorolta a Névtelen használta tizenkilenc annominatio-t, és köztük szerepel az imént idézett szöveghelyen levő pascua Romanorum és Romani pascuntur is. Nincs kizárva, hogy e szójáték egy részét képezte a pastores Romanorum frázis is, hiszen a 9. fejezet utolsó néhány sorában a pastores Romanorum után a pascua, pascebantur, pascua Romanorum és Romani pascuntur szavak fordulnak elő (l. fentebb a 4. szakaszban idézett latin szöveget). Tudva egyrészt azt a hagyományt, miszerint Pannónia a rómaiak legelője volt, másrészt tudomást szerezvén talán közvetve a pápai levelekböl arról, hogy a Bulgari et Blachi frázissal kapcsolatban ott a pastor, pasco és származékszavai bukkannak fel, és a bolgárok és vlachok uralkodói a rómaiak nemes nemzetségéből (ex nobili Romanorum prosapia) származnak évszázadokkkal a korábbi időkre vonatkozóan is, a pascua Romanorum mellett a pastores Romanorum szimbolikus kifejezést is megalkothatta. Anonymus - aki megismerkedett a pápai levelekben oly gyakran megjelenő címzéssel, a dominus Blugarorum et Blachorum-mal, valamint a két országnév együttes előfordulásával (Bulgaria et Blachia) - úgy fogta fel a 13. század elején, hogy a Magyar Királyságtól délre eső területeken, vagyis a Balkánon a római pápaság pásztorai (pastores Romanorum) legeltetik nyájaikat, a bolgárokat és a vlachokat (Bulgarii et Blachii). Regényes Gesztájában pedig ezt az elképzelt vallási és külpolitikai helyzetképet térben északra, Pannóniába vitte, ahol régen a rómaiak legelője (pascua Romanorum) volt, és szlávok laktak. A gesztaíró - aki értesült vélhetőleg arról is, hogy III. Ince pápa 1204. szeptember 15-én kelt levele szerint a bolgár és vlach uralkodó a Magyar Királyság egy részét „visszafoglalni” szán- 
dékozott - arra gondolhatott, hogy évszázadokkal korábban - amikor Simeon, az Első Bolgár Birodalom uralkodója (893-927) és utódai éltek - Pannóniában nemcsak szlávok, hanem bolgárok és vlachok is laktak. Ha óvatosan is, de megkockáztathatjuk azt a feltevést, hogy Anonymus a terram (Pannonie) habitarent Sclaui Bulgarii et Blachii ac pastores Romanorum passzust a most említett szemléletéből inspirálódva öntötte formába.

Azokkal a rómaiakkal kapcsolatban, akik a Névtelen szerint Magyarország javait legelik, hangot kapott olyan vélemény is, miszerint itt a Nyugatról a királynék kíséretében bekötözött lovagok (GYÖRFFY 1965: 420), vagy konkrétabban a 13. század elején érkezett meráni Gertrúd királyné római birodalomból jött német kísérői értendők (KRISTÓ 1978: 632). Nem lehet teljesen kizárni azon nézetet sem, amely ezt a passzust a gesztaíró fanyar ízü megjegyzésének értelmezve a Magyarországon folyó pápai adószedéssel hozta kapcsolatba (GYÖRY 1948: 3536; 1. még SCHÜNEMANN 1926: 450-451). A gesztaíró több vagy tágabb értelemben is használhatta a Romani terminust, amely alatt összefoglalóan feltehetőleg a nyugati egyházi és politikai hatalom képviselöi értendők. A 48. fejezet szerint - amelyben említés történik a Veszprém várát örző római katonákról (milites Romanorum) - ,amikor a magyarok és a rómaiak (Hungarii et Romanii) a határon voltak, a rómaiak (Romani) lappangva átúszták azt a folyót, amely Pannónia és a németek határán (in confinio Pannonie et Theotonicorum) van" (Anon. 1975: 122; vö. Anon. 1999: 41). Itt a Romanii-ban (és a Romani-ban) vélhetőleg német-római alattvalókat láthatunk (VÉSZPRÉMY 2019: 207).

Még egy rövid kitérőt kell tennem a Povest' Vremennych let, vagyis a Régmúlt idők elbeszélése néven ismert írásmüre, amelynek egyes passzusairól néha szó esik Anonymus vlachjaival kapcsolatban. Az elbeszélés idevágó része szerint a voloch-ok (волохи) elfoglalták a szlávok földjét, azután a magyarok elüzték a voloch-okat, örökölték azt a földet, és letelepedtek a szlávok közé (magyar fordítás: PVL. 2015: 18-20, 35; PVL. 2007: 8, 15, 144, 151). ALEKSEJ ŠACHMATOV (1919: 25) már régen megjegyzte, hogy a volochi alatt az elbeszélés összeállítója kétségtelenül Nagy Károly frankjait értette, ami a kontextusból világos, hiszen a voloch-oknak a dunai szlávok fölötti uralma felcserélődik a magyarok uralmával. GYÓNI MÁTYÁS (1989: 332-342; tanulmánya először 1949-ben jelent meg franciául) - többek között ŠACHMATOV hatalmas szövegkritikai munkáit figyelembe véve - szintén ugyanerre az eredményre jutott, és leszögezte, hogy ezt a forrásadatot ki kell iktatni a román történet forrásai közül. (l. még KRISTÓ 1978: 634, 643; PVL. 2007: 587, 5. jegyz.; PETRUCHIN 2011: 13-19; GRZESIK 2016: 31; vö. az elutasító véleményekkel, amelyek ŠACHMATOV alapvető kutatásainak ismerete nélkül fogalmazódtak meg: POP 1996: 83-84; SPINEI 2009: 73-74; vö. MADGEARU 2005: 51-54). Azonban nem tünik meggyőzőnek ama nézet (HóMAN 1925: 60; GYÖRFFY 1965: 417, 1970: 8; vö. GRZESIK 2016: 31-32), miszerint a szóban forgó voloch-ok kapcsolatba hozhatók az anonymusi Blachii-val, és ezen szintén a frankok értendők a szláv hagyományt figyelembe véve. Ha az állítólagos szláv hagyományra támaszkodunk, a szláv vlach vagy ennek többese, a vlasi vagy a vlachi alak kerülhetett be a magyarba, ahol a vlach-ból tudvalevőleg az oláh alak keletkezett, 
az utóbbinak (vlasi > olasz vagy vlachi) pedig nincs köze a Blachii-hoz, hiszen ez - a latin képző elvonásával - nem egy Blachi, hanem egy Blach nevü népet jelöl. Ha magyarázatunk megállja helyét, a Blachii alatt nem értendők sem a frankok, sem valamilyen nyugati eredetủ romanizált nép, legfejebb a vlachokat (románokat) láthatjuk benne, de valódi történeti tartalom nélkül, csak a névalak tekintetében, ami tulajdonképpen a Bulgarii-ra és a pastores Romanorum-ra is vonatkozik, hiszen a passzus nem más, mint a meseszövő gesztaíró fantáziájának szüleménye.

$\mathrm{Az}$ eddig elmondottak egyet nem értést jelentenek azzal a nézettel, amely különböző megközelítésekkel s valamilyen indoklással a Blachii-t és a pastores Romanorum-ot egybetartozónak véli (HÓMAN 1925: 32, 60; SCHÜNEMANN 1926: 454; Anon. 1934/2010: 111; Anon. 1937/1999: 45-46, 7. jegyz.; I. TÓTH 19451946: 52, 55; GYÖRFFY 1965: 418; POP 1996: 84-87; CiOCÎLTAN 1996: 3-7; BREZEANU 1996: 27; PAPACOSTEA 1998: 299-300; MADGEARU 2005: 46-47; BOLLÓK 2013: 513; POHL 2017: 15; CAMARA 2019: 112). ${ }^{21}$

5. Blasii et Sclaui. Anonymus írásmüvében (c. 24-26) Gelou-t az erdélyi vlachok (Blaci) uralkodójaként említi ugyan, de Erdély lakóiként furcsa módon nem a Blaci-t nevezi meg, hanem a Blasii et Sclaui-t, akiknek a kománok és a besenyők (a Cumanis et Picenatis) - a gesztaszerző szerint - sok kellemetlenséget okoztak (Anon. 1999: 26-27; a lengyel fordításban a Blasii a 'bolgárok' szóval van átültetve, ami talán egyszerü figyelmetlenségnek köszönhető, Anon. 2006: 101). Ismétetelten utalni kell arra, hogy a Névtelen elképzelése szerint szlávok (Sclaui) évszázadokkal korábban is éltek a Kárpát-medencében, a Dunántúlon, a Duna-Tisza közén és Erdélyben egyaránt.

5.1. Fentebb már láttuk, hogy a Blasii névalakról milyen nézetek kaptak hangot a szakirodalomban, és a fentiekben elmondottak értelmében nem a Blasii vagy Blasi, hanem a Blas névalakra kerítünk sort. Mivel a Névtelennél megfigyelhetö, hogy az $s$ betüvel a $\check{c}$ hangot is jelölte (KNIEZSA 1952: 80, 82), fontolóra lehetne venni a blač hangalak lehetőségét is, de ilyen etnonima ismeretlen. Ebben a vonatkozásban VÁCZY PÉTER (1974: 36-37, 109-110. jegyz.; vö. I. TÓTH 1945-1946: 58-59, 86. jegyz.) - akinek a véleményére fentebb is utaltam futólagosan - hasznos útmutatást nyújt. Szerinte a Blac és a Blach alakok a latinok balkáni uralma révén gyökeresedtek meg Nyugaton, és ezek kerültek be a magyar írásbeliségbe. A történész - a Névtelen francia környezetére és franciás müveltségére utalva - felhívta a figyelmet arra, hogy Geoffroi de Villehardouin és Philippe Mouskès, akik mindketten Északkelet-Franciaországból származnak, ismerik a Blas alakot, és a Blac alakkal felváltva használják a keresztes hadjáratról szóló franciául írt múveikben. VÁCZY írja, hogy a Névtelen olyanformán cserélgeti a Blas alakot a Blak-kal

${ }^{21}$ HoRVÁTH (1966: 19) különvéleménye szerint - aki a rómaiak említését Bizáncra vonatkoztatta (1. még VeSZPRÉMY 2019: 206) - „Sclavi Bulgari (sic!) et Blachii = ac pastores Romanorum”, vagyis a három nép valamennyien a rómaiak pásztorai. BollóK (2013: 513) szerint Anonymus tudta, hogy a vlach szónak 'pásztor' jelentése van, tehát a Blachii ac pastores kifejezés tautológia, a Romanorum-on pedig a bizánciak értendők. Kevésbé valószínü, hogy a Névtelen a Blachii közszói jelentésére gondolt volna, hiszen szerintem nála a Bulgarii et Blachii egy fogalom lehetett. 
(= Blac-kal? - S. T.), ahogyan a franciául író kortársai, de nem szól egyértelmüen arról, hogy az Anonymusnál szereplő Blach/Blac alak szintén a franciából került-e át hozzá (vö. RÁCZ 2016: 69). Bár pontosításra szorul a nézete (1. alább), miszerint a 13. században uralkodó szabály szerint a többes szám -s jele előtt a mássalhangzó kiesik, és a Blacs helyett a Blas áll a hangzótorlódás elkerülése végett, tanulságosak a példák, amelyeket idézett a két francia szerző müvéből. Villehardouin szemében - aki a IV. keresztes hadjárat saját tapasztalain alapuló krónikása - Johannis (Kalojan) elsősorban Blachia királya, li rois de Blaquie, másodsorban le rois de Blaquie et de Bogrie, ami a pápai levelekben említett uralkodói címzéstől eltér, hiszen a sorrend meg van fordítva, és a Blachia kerül a Bulgaria elé. Mủvéből néhány jellegzetes frázist érdemes idézni: §202: Et cil Johanis si ere uns Blas, §352: que il amenoit Blas et Bogres, et bien XIIII ${ }^{m}$ Cumains, $\$ 404$ : grant gent de Conmains et de Blas, vö. §406: li Conmain et li Blac (GV. 1961. 1: 206; GV. 1961. 2: 160-163, 216-217, 218-219; magyar fordítás: GV. 1985).

Philippe Mouskès müvét most mellőzhetjük, ő nem volt kortársa a magyar Névtelennek. Említésre méltóbb Henri de Valenciennes A Konstantinápolyi Henrik császár története címü írásmüve, amelyet több évvel a latin császár 1216-i halála előtt fejezett be (VH. 1948: 11; KRASIMIRA GAGOVA szerint 1210 táján íródott a mü, VH. 2009: 5). A szerzö, aki érdekes módon nem tesz említést Bulgáriáról s a bolgárokról név szerint, Villehardouin írásmüve után néhány évvel folytatásként leírja a latin császár harcait Boril (Burille), valamint kománjai és vlachjai ellen. Müvéből itt is hivatkozhatunk néhány frázisra: §505: contre Commains et Blas, §521: contre Blas et Commains, §529: de Blas et de Commains, vö. §515: li Commains et li Blac (HV. 1948: 29, 36, 40, 35; bolgár fordítás: HV. 2009). GIUSEPPE STABILE (2010: 94-97) könyvéből, amelyben összegyüjtötte a középkori francia irodalomban elöforduló vlachok neveit a rájuk vonatkozó szöveghelyekkel együtt, világosan látjuk, hogy mind Villehardouin, mind Valenciennes müvében a Blas, valamint a Blac alak többes számban értendö, és csak ritkábban egyes számban. JEAN LONGNON (HV. 1948: 28-29, 3. jegyz.), aki kiadta Henri de Valenciennes müvét, megjegyzi, hogy a Blac többes számban nominativusi alakként (la forme du sujet), a Blas pedig vonzateseti alakként (la forme du régime), és egyes számban fordítva az uns Blas nominativusi formaként, az un Blac pedig vonzateseti alakként használatos. Tehát tulajdonképpen egy Blas etnonimával van dolgunk. Mind a Blas névalak, mind a Blac az említett két francia müben többször előfordulnak. Az ófranciában egy $-s$ végződés jelenléte az egyes számú alanyeset jele, és amikor a $-c$ végződésủ szóhoz az $-s$ hozzáadódik, a $c$ általában az $s$ előtt kiesik, bár néha megmarad: például banc $+s>$ bans ( bancs) (RICKARD 1989: 50; 1. még RAYNAUD DE LAGE 1975: 19). A Blas szóalak is hasonlóképpen keletkezhetett: Blac $+s>$ Blas $(\sim$ Blacs $)$.

5.2. Az Árpád-korban az újlatin nyelveket beszélőknek - akiket a latin forrásokban Latini néven emlegetnek - többsége a vallonokból tevődött össze, és magyarul az olasz névvel illették őket, amelynek a jelentésköre a mainál jóval tágabb volt. Ismeretes, hogy a latinusok egyebek mellett Esztergomban és Székesfehérvárott is - mint iparosok és kereskedők - fontos szerepet játszottak (AUNER 1910; 
ZOLNAY 1960; SZÉKELY 1972; KRISTÓ 2003: 167-177). A magyar-francia nyelvi érintkezésekről szólva BÁRCZI GÉZA (1958a: 110-111; 1. még AUNER 1910: 41; ZOLNAY 1960: 164) megjegyzi, hogy a középkorban, főleg a 11-13. században volt erôs francia hatás a magyar nyelvre, és olyan történeti háttérre is utalt, hogy Imre király feleségével, Arragóniai Konstanciával együtt francia lovagok, egyházi és világi nagyurak is érkeztek Magyarországra. A fent említett Villehardouin (GV. 1961. 1: 110-113, §109; GV. 1985: 39-40) müvéből arról is értesülünk, hogy a keresztesek közül, akik elfoglalták Zárát 1202-ben, egyes francia nagyurak, elhagyván a keresztes hadat, átpártoltak a magyar királyhoz. BÁRCZI szerint „a szerzetesrendek is fontos közvetítöi a francia mủvelődési hatásnak", és a 12-13. században ,sok egyházi személy nyeri legmagasabb iskoláztatását a francia föiskolákon”. A Geszta Előszavából arról értesülünk, hogy Anonymus „legkedvesebb barátjának, N.-nek" - akivel együtt tanult - a kérésére írta meg mủvét, neki ajánlva azt (Anon. 1999: 9). KRISTÓ GYULA feltételezi, hogy III. Béla küldte Anonymust Franciaországba tanulni, ahol barátságot kötött N.-nel (KRISTÓ 1994: 40; GYÖRY [1948: 85] szerint a király nem Párizsba, hanem Orléans-ba küldte ki Anonymust, hogy onnan saját dicsőségének krónikását kapja vissza). SEBESTYÉN GYULA (1898. 2: 92-93) régen leszögezte, hogy Anonymus Párizsban tanult, és ortográfiájában a $h$-s mássalhangzónak franciás értéke van; s felfigyelt arra, hogy a gesztaszerzőnél „Otto, Inn, Ung, Ungari, Ismaelita, Uhot és abundantia helyett Hoto, Hin, Hung, Hungari, Hismahelita, Huhot és habundancia, a hermelin és anherare helyett viszont ermelin és anelare található”, és a másoló „a Hoto helyett írt Athót, az anelare-t rosszul igazítván ki anherare-vá, hanelare-t ír." Szerinte Anonymus következetes ortográfiája közvetlen francia befolyásról tanúskodik. Ide kívánkozik ECKHARDT SÁNDOR (1927: 572) véleménye is, aki rámutatva arra, hogy a $s z$ hangnak $s c$-vel való jelölése megfigyelhető a 13. századi vallon dialektusban írt oklevelekben, úgy véli, hogy a vallon írásmód - amelynek a párizsi franciában meglehetősen korlátozott az elterjedése - közrejátszhatott abban, hogy e hangjelölési mód a magyarban is közönséges volt a 12. és 13. században. Anonymus Gesztájában is, amelyre a Róbert vallon származású kancellár által bevezett helyesírás is hatással lehetett, találunk ilyen írásmódú helyneveket: Scerii, Scereducy és esetleg még Thiscia/Tyscia is (Anon. 1937/1999: 48, 83, 92; c. 11, 39, 40, 44, 45 stb.).

Ilyen körülmények között arra lehet következtetni, hogy a francia mủveltséggel rendelkező Anonymusnak alkalma volt franciául közvetlenül érintkezni a magyarországi vallonokkal és franciákkal, és ugyanakkor megismerkedhetett a vlachok ófrancia nevével, a Blas alakkal is, amely tulajdonképpen a balkáni vlachok jelöléséül szolgált ófranciául. A gesztaírónak tudomása lehetett a dél-erdélyi vlachokról is, akiket a II. András korabeli királyi kancelláriában Blac névvel illettek, és még arról is, hogy Erdélyben vallonok is laknak (KLEIN 1963: 231-233; vö. még KRISTÓ 2003: 175-176). Feltehetőleg ennek tudható be, hogy Erdély lakóinak neveként a vlachok franciás nevét, a Blas-t (> Blasii-t) is alkalmazta a Blac mellett, amely pedig egybeesett a Blas többes számú alakjával az ófranciában. Nincs kizárva, hogy nemcsak a Blas(ii), hanem a Blac(i) is, amelyeket Anonymus Erdély lakóinak nevéül használt, mind az ófrancia névalakokra 
vezethetők vissza, amelyek pedig a balkáni vlachok jelölésére szolgáltak. Kevésbé valószínü, hogy a Blas kapcsolatos lenne a magyar 'olasz' szó korabeli alakjával, illetve az erdélyi vallonok nevével.

Egyúttal megemlítendő, hogy a gesztaíró a besenyők nevének idegen nyelvi alakját (Picenati) talán valamilyen keresztes hadjáratra vonatkozó nyugati eredetü latin forrás balkáni vonatkozásaiból kölcsönözhette (I. TóTH 1945-1946: 61-62, 84; szerinte az anonymusi Picenati névalak talán egy francia eredetü latin forrás reminiscentiája; 1. még GYÖRFFY 1965: 426). Anonymus feltehetőleg úgy képzelte el, hogy a balkáni Blas-ok korábban Erdélyben laktak a szlávokkal együtt (Blasii et Sclaui), és azért, hogy elmesélését archaikusabbá tegye, felhozta a Cumanis et Picenatis frázist is, amelyet nem meríthetett a magyar hagyományból. Úgy tünik, hogy Anonymus - aki többször következetlenül járt el a különféle nevek írásmódjával - tisztában volt azzal, hogy mind a Blac-ok (Blaci) és a Blas-ok (Blasii) etnikailag egy csoportba tartoznak, továbbá azzal is, hogy az általa emlegetett Bisseni/ Bysseni azonos a Picenati-val (vö. I. TóTH 1945-1946: 58, 85. jegyz.).

5.3. Az Anonymusnál szereplö Blasii-val kapcsolatban a szakirodalomban többször történik hivatkozás egy, a 14. század elején készült földrajzi munkában található Blazi és Blachorum névalakokra, így most ezzel kapcsolatban is kis kitérőt kell tennünk. Az említett névalakokról szó esik ugyanis a Descriptio Europae Orientalis (a továbbiakban: DEO.) címen ismertté vált dokumentumban, amelynek autográf kézirata nem maradt ránk, és amelyet gyakran ismeretlen szerzőtől származtatnak. OLGIERD GóRKA (DEO. 1916: IX-XVI), aki 1916-ban öt középkori kódexben fennmaradt szöveg alapján elkészítette annak kritikai kiadását, valószínünek vélte, hogy a szerző egy francia domonkos szerzetes volt, akinek müve 1308-ban készült. 2013-ban a DEO. kritikai kiadására másodízben is sor került egy szerb kutatócsoport gondozásában. Véleményük szerint az írásmü 1311 táján készült, és szerzője nem Valois Károlyhoz állt közel, hanem a pápai kúriához, V. Kelemen pápa köréhez (DEO. 2013: 42-43, 63-64, 186-187). Időközben olyan nézet is hangot kapott, miszerint a szerző Andreas Hungarus mester, aki igen idős korban írta meg, talán Antivari (olaszul: Bar, Montenegró déli részén) érsekeként (DEO. 1987-1988: 13; SULYOK 1994: 98). Mások úgy vélik, hogy egy olasz lehetett az írásmü szerzője (KONOVALOVA 2020: 102).

MELICH (1925-1929: 310-311) régen úgy foglalt állást, hogy a latin blazi alak az Anonymus-féle blasij-nak az alakváltozata, és a blachus névnek - amely a DEO.-ban is elöfordul a Blachorum formában - nemcsak blaci ( *blakci), hanem blasi ( blazi) többes számú alakja is volt. Fentebb már láttuk, hogy a nyelvész hogyan magyarázta a blasi alakot. Nem könnyü nyomon követni komplikált eszmefuttatását, de annyi megjegyezhető, hogy az ő kiindulópontjával, kérdésfeltevésével nem értek egyet, hiszen a blasij, illetve Blasii nem más, mint a Névtelen agyában kreált Blas +ius (nem Blasi+us) többes számú alakja. MADGEARU (2005: 56) megjegyzi, hogy a DEO.-beli „Blazi (Blasi)” alak Anonymus Gesztájában is előfordul, és azután megváltoztatva névalakjukat tovább írja, hogy a „Blasii/ Blazii" név egy nyugati szláv fonetikai formával rendelkezik, és mind a két névtelen szerző a Magyarországon még élt szlávoktól kapott információt múvéhez. 
A Blazi/*Blasi és a Blasii/*Blazii között meglévő alaki eltérés tisztázása nélkül véleménye nem igen meggyőző (1. még BREZEANU 1996: 24, 30; vö. STABILE 2010: 35). Ismételten hangsúlyozandó, hogy azon nézet nem helytálló, miszerint a Blasi (sic!) névalakot a szláv vlach többes számú alakjával, a vlasi-val lehet összefüggésbe hozni, hiszen Anonymus nem a szláv vlasi-ból képezte a többes számú Blasii névalakot, hanem a Blas (+ius) névalak alapján.

A DEO. szerzője - aki minden bizonnyal tudhatott franciául, és személyesen járt a Balkánon - a következőképpen ír: „Macedonia, Achaja és Thesszalonika között él egy bizonyos nagyon nagy és elterjedt nép, akiket blazi-nak neveznek (quidam populus ualde magnus et spatiosus qui uocantur Blazi), és akik hajdanán a rómaiak pásztorai (Romanorum pastores) voltak, és Magyyarországon időztek, ahol a rómaiak legelői (pascua Romanorum) voltak, mert a föld termékeny volt és üdén zöldellt. De végül is a magyarok kiüzték őket onnan és ide menekültek" (magyar fordítás: DEO. 1987-1988: 15-16; DEO. 1916: 13). Azután nevüket a Blach-ra változtatva írja, hogy „ezeknek a blachoknak földjét (terram ... Blachorum)" elfoglalta Valois Károly. A DEO. Magyarországról szóló részében azt olvassuk, hogy „A pannonok pedig, akik akkoriban Pannóniában laktak, valamennyien a rómaiak pásztorai voltak (Pannoni autem qui inhabitabant tunc Pannoniam omnes erant pastores Romanorum)" (magyar fordítás: DEO. 19871988: 22; DEO. 2013: 134).

GÓRKA 1916-os szövegkiadásához és az ennek alapján készült magyar fordításhoz egy-egy megjegyzést füznék. A fordításban szereplő blazi alak helyett magyarul a blaz-ok tartható helyénvalónak, hiszen nem egy Blazi, hanem egy Blaz népnévröl van szó. ${ }^{22}$ A szöveg újabb kiadója a GóRKA-féle kiadásban szerepelt Blazi-t Blachi-ra javította át (DEO. 2013: 102), ami bizonyára annak köszönhetö, hogy a néhány sorral alább szereplö Blachorum alakot hitelesnek vélték. ${ }^{23} \mathrm{Ez}$ a beavatkozás nem megfelelö, hiszen a kérdéses szöveghelyen egyik kéziratban sem szerepel a Blachi alak. Három kéziratban, amelyek egy közös kézirati hagyományba tartoznak, Blazi, egy kéziratban (cod. lat. 66, Leiden) pedig Blasi fordul elő (DEO. 2013: 102, 337. jegyz.), így GóRKA a Blazi névalakot választotta. Azonban a Blaz forma ismeretlen az ófrancia irodalomban (STABILE 2010:

${ }^{22}$ Akkor viszont helyesen jártak el a fordítók, amikor a DEO.-ban szereplö ,, qui alio nomine Huni uocantur” (DEO. 2013: 135) frázist ekként tolmácsolták: „akiket más néven hunoknak (nem huninak!) hívnak" (DEO. 1987-1988: 23). Mellesleg megjegyzem, hogy PoP (1996: 87) angol nyelvü könyvében a Blazi „the Romanian people”-re változik a fordításban, POPA-LISSEANU (1934/2010: 60) román fordításában pedig szöveghủen a blazi-t szerepelteti.

${ }^{23}$ Csak kuriózumként említeném meg, hogy MiLoš CVETKOVIĆ (2018: 48-54) - aki magáévá teszi ezt a Blachi-féle javítást - hitelt ad a DEO. leírásának a vlachok Magyarországról Thesszaliába való vándorlásáról, támaszkodva MADGEARU véleményére, s Anonymus gesztája alapján arra következtet, hogy a vlachok 896 és 904 között Pannóniából oda érkeztek. Mindenesetre fel lehet figyelni a különbségre a két névtelen szerző felfogása között a tekintetben, hogy a magyar Anonymus a magyar seregekkel nem űzeti ki a vlachokat se Pannóniából (a Blachii-t), ahová egyébként a szlávokat és a bolgárokat is helyezte, se Erdélyből (a Blasii-t, illetve Blaci-t), hanem csupán legyőzeti; a másik névtelen szerző pedig onnan, ahol mintha csakis a vlachok laktak volna, elmenekíti őket délre a Balkánra (másképpen PILLON 2005: 82). 
94-95) és más forrásokban (ARMBRUSTER 1990: 31-33) is. A kutatás rámuttott arra, hogy a DEO.-ban a magyar krónikákkal közös motívumok találhatók (különösen pascua Romanorum és Romanorum pastores, pastores Romanorum; DEO. 2013: 102, 134; 1. DEÉR 1931: 13-15; TAMÁS 1935: 215-216; KRISTÓ 1978: 652; SULYOK 1994: 104-105), de a Blazi névalakról aligha szólt, kivéve a fent hivatkozott MELICHet és MADGEARUt. A magyar krónikák közül szerintem Anonymus gesztája az, amelyből leginkább merített közvetve vagy közvetlenül a DEO. szerzője. A Blazi és a Blasii ugyanis össszeköti a két Névtelent, amire a DEO. egyik kéziratában szereplő Blasi névforma a tanú. Így nem indokolatlan a Blazi helyett Blasi formát szerepeltetni a DEO. kérdéses szöveghelyén.

A DEO.-féle Blasi és az Anonymusnál szereplő Blasii névformák keletkezési körülményeit a következőképpen lehet összefoglalni. Ami a gesztabeli Blasii-t illeti, ahogy fentebb láttuk, a magyar Anonymus a Blas névalak ismeretében egy egyes számú *Blasius alapján képezte a többesét, a Blasii-t. A DEO. szerzője pedig, aki szintén ismerhette a vlachok ófrancia nevét, ebből a Blas-ból - egy szokásos latin végződéssel ellátott egyes számú *Blasus alak alapján - hozta létre a többesét, a Blasi-t. A névtelen író, aki tudhatta, hogy a vlach szónak 'pásztor' jelentése is van, felfigyelt a magyar Anonymus kérdéses passzusából a Blachii ac pastores Romanorum szókapcsolatra, aminek következménye - ahogy egyes jelenkori kutatóknál is megfigyelhetö - az lett, hogy a rómaiak pásztorait azonosnak vélte a Blas-okkal, illetve a Blach-okkal. Így mind a Blas-okat (Blasi/Blasii-t), akiket a magyar Névtelen jegyző Erdélybe helyezett, mind a Blach-okat (Blachi) Blachii-t), akiket szintén ő Pannóniába tett, egybetartozóknak vélve most onnan Thesszália vidékére költöztette, tudomást szerezvén arról, hogy ott hasonló nevet viselő népcsoport él. Ez utóbbiak az aromán (macedoromán) népcsoport ősei le-

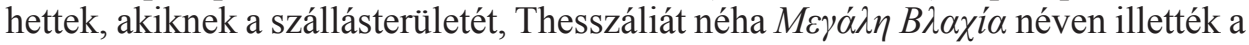
bizánciak (SoULIS 1963: 273; DEO. 2013: 155-156). Ez az elnevezés tükröződhet abban a kifejezésben, hogy a Blas a „nagyon nagy és elterjedt nép (populus ualde magnus et spatiosus)" és a Blach-ok földje „nagy és gazdag (magna et opulenta)”.

5.4. Ezek után a pastores Romanorum kifejezésre ismét sort kell kerítenem röviden, amelyre vonatkozóan különböző nézetek kaptak hangot a szakirodalomban, ${ }^{24}$ és amelynek eredetéről egyértelmü bizonyossággal nem lehet állást foglalni. KRISTÓ GYULA (1978: 656) a fentebb idézett vélekedése után - más megközelítésből kiindulva - megjegyzi, hogy a vlachokkal kapcsolatban Kézai Simon a 13. század végén ugyanazt a magyar forrást használta, amely már Anonymusnak is

${ }^{24}$ Erről a problematikáról 1. Anon. 1988: 237-238; Anon. 1991: 150-151, 90-91. jegyz.; Anon. 1999: 56, 74-75. jegyz.; Anon. 2000: 125, 22. jegyz.; Anon. 2001: 23, 36. jegyz.; Anon. 2006: 58-59, 81. jegyz.; Anon. 1934/2010: 112, 2. jegyz.; HÓMAN 1925: 60; SCHÜNEMANN 1926: 452-455; MACARTNEY 1940a: 161-164; GYÖRFFY 1965: 418-420; KRISTÓ 1978: 652-657; ARMBRUSTER 1990: 39-40; DELETANT 1991: 339-341; BREZEANU 1996: 18-31; MADGEARU 2005: 45-57; GRZESIK 2016: 30-32; VESZPRÉMY 2019: 205-207. Újabban CSÁKÓ JUDIT (20192020) a pascua Romanorum szókapcsolatnak szentelt részletes tanulmányt, beleértve a pastores Romanorum kifejezést is. A jelen dolgozatban, amelyet 2020 februrjában küldtem be a Szerkesztőségnek, sajnos nem áll módomban figyelembe venni CSÁKÓ tanulmányának időközben - talán 2021 elején - megjelent második részét. 
rendelkezésére állt, és amely tudott a rómaiak legelőjéről, ismerte a rómaiak pásztorait, bár Kézai ugyanebből a nyersanyagból a Névtelentől egészen eltérő következtetésre jutott. Azonban - ahogy a történész is írja - a pastores Romanorum frázis nem fordul elő Kézai krónikájában (Blackis, qui ipsorum fuere pastore et coloni, remanentibus sponte in Pannonia; c. 14, SRH. 1: 157; KS. 1999a: 98; KS. 1999b: 54-55; 1. még SRH. 1: 269) - noha Kézai szerint a vlachok (Blacki) az Attila kori római városlakók pásztorai és kolónusai voltak -, és a vlachok nevének formája merőben eltér az Anonymusnál megjelenő adatoktól. GYÖRFFY GYÖRGY (1965: 417-418, 420; MACARTNEY 1940a: 160-161), arra gondolván, hogy a helyi szláv hagyomány szerint Pannónia vlach, azaz frank uralom alatt volt, feltételezi, hogy a vlachok és a római pásztorok együttes szereplése a régi gesztára vezethető vissza. Szerinte a pascua Romanorum motívumból „,erednek a 9. fejezet pastores Romanorumjai, utóbbiból nőttek ki a 11. fejezet principes Romanorumjai" (1. még GYÖRFFY 1993: 22-23, 149-150). Fentebb már láttuk, hogy GYÖRFFY itt a Blachi-ra (Blachii-ra) gondol a vlachokkal, vagyis szerinte a frankokkal kapcsolatban, ami azonban nehezen fogadható el.

A pascua Romanorum fordulatot illetőleg a kutatás már régen rámutatott arra, hogy több közel egykorú - Anonymus gesztájánál néhány évtizeddel későbbi - forrásban, Riccardus fráter jelentésében (SRH. 2: 535), Spalatói Tamás Historia Salonitana (HS. 62-63, c. 14) címü múvében és a Sittichi Rímes Krónikában (SRH. 2: 606) említés történik erröl. ${ }^{25}$ A Névtelen is bizonyára ismerte ezt a hagyományt, miszerint Pannonia (vagy a szinonimájaként használt Hungaria) a rómaiak legelője volt. Az más kérdés lehet, hogy a pascua Romanorum latin kifejezést elöször mikor foglalták írásba, ami nem lehet korábbi a 12-13. század fordulójánál (vö. KRISTÓ 1978: 654), és ez akár magától Anonymustól is származhatna (BUJÁK 2019: 418). A pascua Romanorum szókapcsolatról egy, a 13. század közepén íródott mü, a Descripciones terrarum (a továbbiakban: DT.) is szól, amely a 20. század utolsó negyedében került elö. Eszerint a terra Vngarorum előző lakói hunoknak nevezett szlávok voltak - bolgárokról és vlachokról nem esik szó -, és később magyarok vették birtokukba ezt a földet, amely a rómaiak legelője (pascua Romanorum) volt. ${ }^{26}$ Azon híradás alapján, hogy a hunoknak nevezett szlávok lakják a pascua Romanorum-ot, VESZPRÉMY LÁSZLÓ (2019: 206; vö. CSÁKÓ 2019-2020: I. rész. 179-181) úgy véli, hogy a frázis nyugatról került a magyar tollforgatókhoz, és Anonymus nem magyar hagyományból, hanem egy nyugati eredetü szóbeli vagy írott hagyományból merítette a pascua Romanorum kifejezést. Valószínübb azonban, hogy a hunoknak a szlávokkal való azonosítá-

${ }^{25}$ HÓMAN: 1925: 60; DEO. 1934/2010: 12-13 (G. POPA-LISSEANU írása); MACARTNEY 1940a: 160-161; GYÖRFFY 1965: 418; KRISTÓ 1978: 653; ARMBRUSTER 1990: 39-40.

${ }^{26}$ MARTIN L. COLKeR (1979: 713-714., 14. jegyz., 721) fedezte fel ezt a rövid írásmüvet Dublinban, és 1979-ben a latin szöveget ki is adta. L. S. ČEKIN (1993: 213, 221) is közölte a latin szöveget orosz fordítás kíséretében. Azt, hogy a DT.-ban - amelyet szerzöje szerint a tatárokról szóló műve bevezetésének szánt - az európai városok közül egyedül Anteuaria-ról (ol. Antivari, Bar, Montenegró) történik említés (COLKER 1979: 724; ČEKIN 1993: 215), a kutatás azzal hozta kapcsolatba, hogy Plano Carpini, aki 1247-ben tért vissza Európába a mongoloktól, 1248 és 1252 között Antivari érseke volt (KORAĆ- RADIĆ 1998: 254, 257; FREIBERGS 1999: 197). 
sára nézve a DT. szerzöje lengyel hagyományra támaszkodott. GUNAR FREIBERG (1999: 184-185, 193-194) szerint - aki tüzetes vizsgálat alá vette a kútfő́t - a DT. 1255-ben íródott, és szerzője Jacek Odrowąż lengyel domonkos volt. A domonkos szerzetes magyar kapcsolataira utalva lehetségesnek tartja, hogy a szerző magyar - többek között - domonkosrendi kapcsolatai révén ismerte a kifejezést, amelynek forrásául közvetve az elveszett Gesta Ungarorum szolgált (hasonlóképpen COLKER 1979: 713-714, 14. jegyz.; ČEKIN 1993: 221). Nem feltétlenül erre a feltételezett régi gesztára kellene azonban gondolni, hanem akár magához Riccardus domonkos szerzetes jelentéséhez is lehetne visszavezetni közvetve vagy közvetlenül az itt tárgyalt kifejezés forrását. A pascua Romanorum kifejezés tehát mindössze négy 13. századból származó munkában fordul elő, amelyek mind Anonymus gesztájánál később keletkeztek, de egyikükben sem történik említés a bolgárokról és a vlachokról. Ezek a körülmények egyrészt arra engednek következtetni, hogy a Bulgarii et Blachii ac pastores Romanorum passzust maga Anonymus hívta életre, másrészt pedig arra is, hogy lehetett egy közel egykorú szöveg vagy geszta, amelyben írásba volt foglalva a pascua Romarorum kifejezés. Ezzel szemben több jel mutat arra, hogy a DEO. szerzöje a magyar Anonymus gesztájából közvetve vagy közvetlenül meríthetett néhány kifejezést, de csak a Blas/Blach-okat szerepeltette Hungaria előző lakóiként.

(Folytatjuk.) 